\title{
Ontogeny of the gastrointestinal tract of marine fish larvae
}

\author{
J. L. Zambonino Infante* and C. L. Cahu \\ Unité Mixte INRA-IFREMER de Nutrition des Poissons, IFREMER, BP 70, 29280 Plouzane, France \\ *: Tel.: +33-298-224090; fax: +33-298-224653; email: jlzambon@ifremer.fr
}

\begin{abstract}
Marine fish larvae undergo major morphological and cellular changes during the first month of life. The ontogeny of the gastrointestinal tract combines these two aspects of the larval development and is very interesting in that the timing of functional changes appears genetically hard-wired. The goal of this paper is to give an overview of the gastrointestinal development process in marine fish larvae, with particular attention to three species: sea bass; red drum; and sole, since the description of gut maturation in fish larvae was initiated during the last decade with these species. During the early stages, marine fish larvae exhibit particular digestive features. Concerning the exocrine pancreas, amylase expression decreases with age from the third week post-hatching in sea bass and red drum (approximately 400 degree days), whereas expression of other enzymes (trypsin, lipase, phospholipase A2...) increases until the end of the larva period. Moreover, secretory function of the exocrine pancreas progressively develops and becomes efficient after the third week of life. Concerning the intestine, enzymes of the enterocyte cytosol (in particular peptidase) have higher activity in young larvae than in older. Approximately in the fourth week of post-hatching development in sea bass, red drum and sole larvae, the cytosolic activities dramatically decline concurrently with a sharp increase in membranous enzyme activities of the brush border, such as alkaline phosphatase, aminopeptidase $\mathrm{N}$, maltase... This process characterises the normal maturation of enterocytes in developing fish larvae and also in other vertebrates' species. The establishment of an efficient brush border membrane digestion represents the adult mode of digestion of enterocytes. This paper also describes the role of diet on the development of the gastrointestinal tract. Indeed, the maturational process of digestive enzyme can be enhanced, stopped, or delayed depending on the composition of the diet.
\end{abstract}

Keywords: Aquaculture; Development; Digestion; Enzyme expression; Fish larvae; Glucides; Intestinal enzymes; Larvae feeds; Lipids; Pancreatic enzymes; Proteins 


\section{Introduction}

Over these two last decades, marine fish hatcheries have been faced with an increasing demand of juveniles due to the development of marine fish aquaculture. Nutrition of marine fish larvae still relies on live prey (Artemia) production; the high and fluctuating costs of this production and the lack of formulated diet suitable for marine fish larvae retard the development of marine fish aquaculture.

Compound diet substitution for live prey has been the subject of many studies (Watanabe and Kiron, 1994; Rønnestad et al., 1999; Yufera and al., 1999). Some authors, considering that young larvae had insufficient digestive enzyme capacity, moved towards the supply of exogenous enzymes in compound diets (Kolkovski and al., 1993 and 1997). This approach led to some positive results in rearing of gilthead sea bream larvae, but has never been conclusive in other fish species (Kolkovski, 2001). It has been then suggested that live food may provide factors that stimulate larval pancreatic secretions stimulating endocrine responses (Koven et al., 2001).

More recently, others considered that young larvae cannot handle dietary components in a manner exactly analogous to that of juveniles because of digestive features characteristic of post-natal stages (Cahu and Zambonino Infante, 1995; Péres et al., 1996; Buchet et al., 1997). This approach was inspired by the knowledge gained for land vertebrates and in particular mammals (Henning, 1994).

Digestion processes are well known in growing vertebrates including fish. The digestion of nutrients occurs in the gastrointestinal tract and is performed by the enzymes of the stomach, exocrine pancreas and intestine but also includes the absorption/transport of nutrient by the intestinal cells (not reviewed in this paper). Stomach, exocrine pancreas and intestine produce different types of enzymes. An acidic protease activity is mostly found in the stomach; this activity is due to the activation of pepsinogen in pepsin. The exocrine pancreas synthesizes 
and secretes in the intestinal lumen a large number of enzymes, glucosidases, lipases and proteases; these proteases work at alkaline $\mathrm{pH}$, after activation by trypsin, itself activated by enterokinase, the sole enzyme secreted by intestinal cells. Most of the available information on secretion and activation of pancreatic enzymes has been obtained in upper vertebrates, and has been well reviewed by Scheele and Kern (1993) and Lowe (1994). The intestinal cells, also called enterocytes, have two types of enzymes: the cytosolic enzymes (mainly peptidases) found in the cell cytoplasm, and the brush border membrane enzymes, which are linked to the cell membrane. Different types of membranous enzymes can be detected: peptidases, disaccharidases, esterases. These different enzymes found in the gastrointestinal tract are often complementary; this enzymatic process lead to the total digestion of diet components in nutrients allowing their absorption or transport by enterocytes.

Digestion mechanisms in fish larvae have been particularly studied during the last 2 decades. These studies were conducted in order to develop a formulated compound diet for replacing live preys in hatchery.

This review aims to describe the ontogeny of digestive functions in marine fish larvae, with a particular attention to sea bass, red drum and sole.

\section{Development of the gastrointestinal tract in three marine fish larvae species}

Stomach, pancreas and intestine are not totally mature at hatching; these organs undergo some morphological and functional changes during the development of the larvae.

\section{II-1 Stomach}

From an anatomical point of view, this organ is more or less developed in adult fish depending on the species. 
The transition between oesophagus and stomach is not anatomically visible from day 7 post-hatching onwards in sea bass larvae ( $\mathrm{Vu}, 1976)$. The development of stomach is nearly complete around day 15 (Walford and Lam, 1993). The appearance of gastric glands around day 25 indicates the timing of stomach development from a histological point of view. Moreover, pepsin activity can be detected at this developmental stage (Walford and Lam, 1993; Zambonino Infante and Cahu, 1994).

The stomach of sole larvae is more distinguishable than sea bass larvae, and by day 10 post-hatching, the elongation of the epithelial cells delineates precisely the passage from oesophagus to the stomach (Bouhlic and Gabaudan, 1992). By day 22, the first gastric glands are observed, but pepsin activity has never been detected during the first 5 weeks of life. A pepsin-like activity has been only detected in 200-day-old animals (Clark and al., 1986). It can be pointed out that in another flat fish (Pleuronectes americanus) the appearance of gastric glands coincided with the detection of pepsinogen RNA messengers (Douglas et al., 1999b).

In red drum, the stomach is well differentiated as early as day 7 post-hatching (Holt et al., 1981).

\section{II-2 Exocrine pancreas}

In sea bass larvae, the differentiation of exocrine cells and the appearance of the excretory duct occur at day 3 post-hatching, before mouth opening. The presence of zymogen granules and of the pancreatic duct (called duct of Wirsung) characterizes these events (Beccaria et al., 1991). Trypsin activity can already be detected at this developmental stage (Zambonino Infante and Cahu, 1994); a sharp increase in trypsin and amylase activities coincides with the mouth opening (day 5), and corresponds to the first secreted zymogen granules (Beccaria et al., 1991). 
The first zymogen granules are observed at day 2 in sole larvae, coinciding with mouth opening. The day after, the duct of Wirsung opens out in the foregut (Bouhlic and Gabaudan, 1992). Ribeiro et al. (1999b) also reported elevated amylase and trypsin enzyme activities in sole larvae at the time of mouth opening; the presence of enzymatic capacity before first feeding suggests that those activities were not induced by food.

Shortly after mouth opening, it is possible to detect a wide spectrum of enzymes in young marine fish larvae. Table 1 summarizes the different pancreatic enzymes detected in sea bass, sole and red drum, and their time of detection.

Table 1. Detection of different pancreatic enzymes in three marine fish larva species.

\begin{tabular}{lcccc}
\hline \multicolumn{5}{l}{ Time of detection (day after hatching) } \\
Enzyme & sea bass & sole & red drum & references \\
\hline $\begin{array}{l}\text { Trypsin } \\
\text { Chymotrypsin }\end{array}$ & 4 & 2 & 1 & $7,31,43,55$ \\
& 5 & 5 & - & 1,2 \\
Amylase & 4 & 3 & 1 & $7,31,43,55$ \\
& & & & \\
Lipase & 5 & 2 & 1 & $22,31,36,42$ \\
Phospholipase A2 & 9 & - & 10 & $8,36,57$
\end{tabular}

All the enzymes assayed in total larvae body homogenate have similar pattern of expression; indeed, the total activities of the pancreatic enzymes increases with age, due to increases in both tissue weight and enzyme activity per gram of tissue proteins; a general decline in enzyme activity per gram of protein is then always observed. The time of the 
decrease in specific enzymatic activity (activity per gram of protein) depends on the species (fig 1): around the third week of life in sea bass (Zambonino Infante and Cahu, 1994) and red drum, and the $10^{\text {th }}$ day of life in sole (Martinez et al., 1999; Ribeiro et al., 1999b). The decline in specific enzyme activity is not due to a diminution in enzyme synthesis but is the result of an increase in tissue proteins; this increase in protein can be related to anatomical and physiological modifications in the three fish species, constituting a step in the metamorphosis. This particular enzymatic profile is specific of early stages, and characterizes post-natal changes in the activity of digestive enzymes in fish larvae as well as other vertebrates including mammals (Henning, 1987). Following this decline, pancreatic enzyme activities remain at a constant level generally until the end of the larval development (around one month).

Fig. 1. Expression pattern of trypsin during the post-hatching development of sole and sea bass larvae (from refs. 43 and 55).

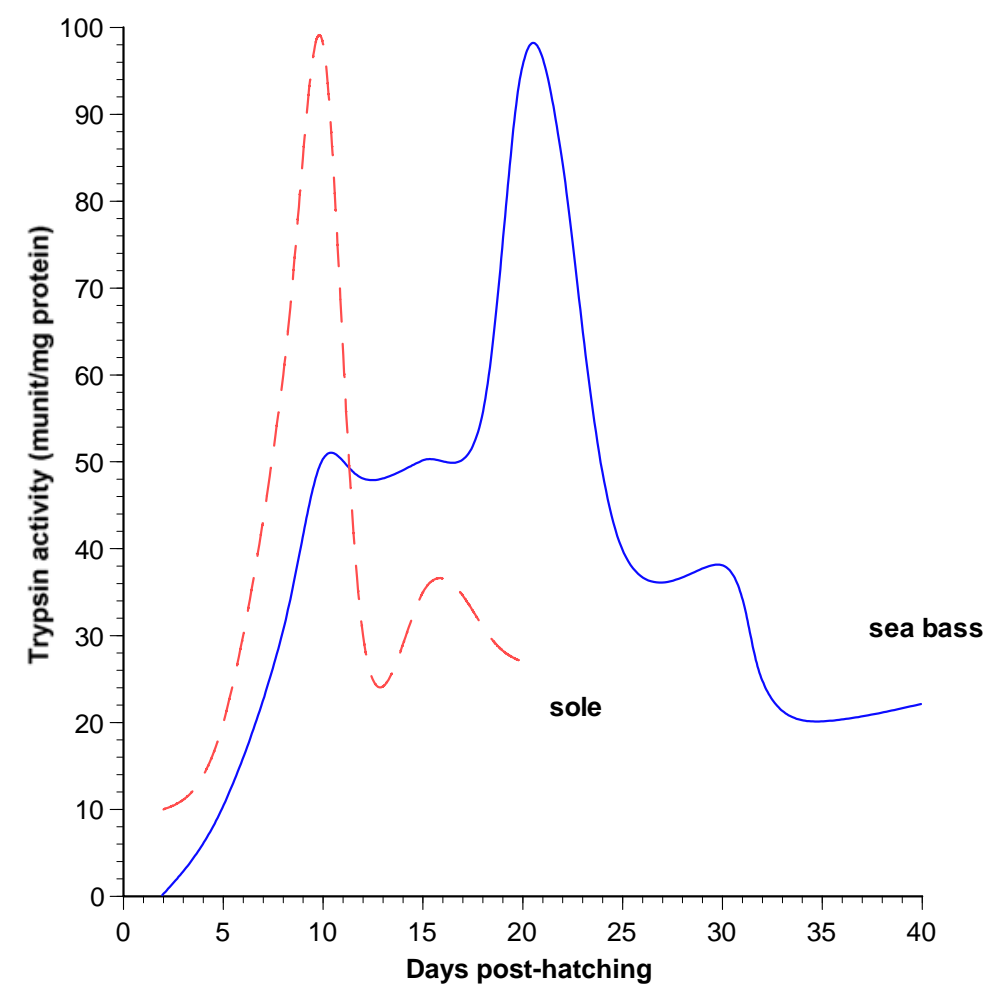


Amylase specific activity is very high during the young larval stages and markedly decreases during larva development (Zambonino Infante and Cahu, 1994; Ribeiro et al., 1999b; Buchet et al., 2000). Péres et al. (1998) demonstrated that higher amylase mRNA levels are found in young sea bass larvae than in older larvae, and suggested that the coordinated decrease between specific activity and mRNA levels of amylase is transcriptionally regulated during larval development (Fig. 2). In the winter flounder, Douglas et al. (2000) also showed that amylase transcripts peaked around day 20, then decreased during metamorphosis. Moreover this decrease in amylase is observed irrespective of the dietary glucide concentration (Péres et al., 1996), which suggests that the decrease in amylase activity during larval development is genetically programmed. This particular change in amylase may reflect different nutrient requirements at different stages of life (Krogdahl and Sunby, 1999), as evoked for the first time by Buddington (1985) for lake sturgeon larvae.

Fig. 2. Activities and mRNA levels of amylase during the development of sea bass larvae fed a diet containing $5 \%$ glucides (unbroken lines) or $25 \%$ glucides (broken lines). Data were obtained from refs. 39 and 41 .

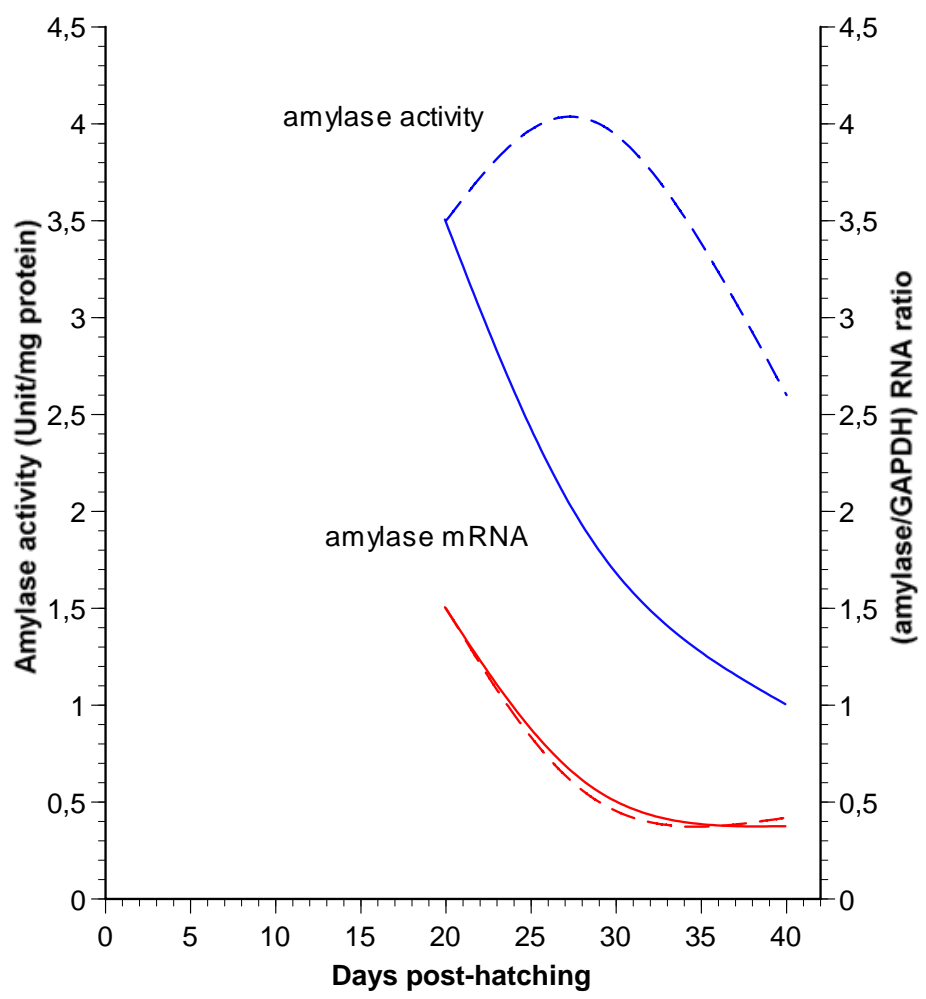


The pancreatic secretion has been studied using different approaches on dissected larva segments: some authors cut marine fish larvae in 4 parts head, pancreatic segment, intestinal segment and tail, in order to assay the enzymes in specific segments (Pedersen and Andersen, 1992; Cahu and Zambonino Infante, 1994). This simple dissection allows the distinction between proenzymes and enzymes using specific antibodies (Pedersen and Andersen, 1992) or by spectrophometric assay of enzymes present in pancreas and in intestinal lumen (Cahu and Zambonino Infante, 1995). The amount of pancreatic enzymes detected in the intestinal lumen increases with larval development. Some authors (Krogdhal and Sudby, 1999) suggested that the mechanisms involved in pancreatic enzyme secretion in fish larvae develop later than those involved in synthesis as it was reported in mammals (Henning, 1987). Complete achievement of the secretory process of pancreatic enzymes in larvae of red drum, sole and sea bass occurs around day 18, day 21 and day 25 respectively (Cahu and Zambonino, 1994; Buchet et al., 1997; Ribeiro and al., 1999b), which approximately corresponds to 500 degree-days.

\section{II-3 Intestine}

As early as the third day of life, the intestinal epithelium of sea bass larvae has a regular surface and the enterocytes initiate their apical differentiation by establishing a brush border membrane (Vu, 1976). Thickening and undulations in intestinal epithelium were noted around day 7. This event coincides with an enhanced activity of some membranous enzymes (Zambonino Infante and Cahu, 1994). Around day 14, the intestinal epithelium has numerous microvilli at the luminal surface forming the brush border (Walford and Lam, 1993). 
Folding of the mucosa increases from day 25, concomitantly with a sharp increase in the activity of enzymes located in the brush border membrane of enterocytes (Cahu and Zambonino Infante, 1994).

In sole larvae, the anterior two-thirds of the intestine has regular mucosa at hatching; in the posterior third of the intestine, the enterocytes already show an apical striated border (Bouhlic and Gabaudan, 1992). With larval growth, the gut is elongated and the intestinal lumen is more corrugated due to the mucosal folds that appear at day 3 (Ribeiro et al., 1999a). As noted for sea bass, the increase in folding of the mucosa is concomitant with a strong elevation in activity of some digestive enzymes located in the cell membranes (Sarasquete and al., 1996). From day 10 up to day 30, the intestinal folds become more abundant and the thickness of the brush border of enterocytes increase, indicating an increase in digestion and absorption area. Some authors (Ribeiro et al., 1999b) reported a sharp elevation in alkaline phosphatase activity assayed in intestinal brush border membrane preparations, occurring at this time.

The general pattern of intestinal enzyme expression during larval development is similar to that already described for pancreatic enzymes: an increase followed by a decline in enzyme activity is also noted when membranous enzymes are assayed in whole larvae homogenate (Zambonino Infante and Cahu, 1994). Nevertheless, a specific post-natal change in the activity of intestinal enzymes can be observed considering some enzymes, such as leucinealanine peptidase and alkaline phosphatase distributed in two different subcellular areas of enterocytes, the cytosol and the brush border membrane respectively. During the first 3 weeks of life, intracellular digestion of protein by cytosolic peptidases exhibits very high activities particularly when the extracellular digestion by pancreatic proteases as well as by intestinal microvillus enzymes has not yet matured. This phenomenon has been well 
described in mammals (Himukai and al., 1980; Henning, 1987) and in fish (Cahu and Zambonino Infante, 1995). The cytosolic enzyme activities progressively decrease with larval growth when the activities of the brush border membrane enzymes abruptly increase around the third week post-hatching in sea bass (Cahu and Zambonino Infante, 1994), sole (Ribeiro et al., 1999b) or red drum (Buchet et al., 1997). The marked decrease with age of leucine-alanine peptidase activity in the cytosol, and the concurrent and sharp increase in alkaline phosphatase and aminopeptidase $\mathrm{N}$ in intestinal brush border membranes (Fig. 3) characterizes the normal maturation of the enterocytes in developing fish larvae, and also in other species including mammals. The establishment of an efficient brush border membrane digestion represents the adult mode of digestion by enterocytes (Henning et al., 1994).

Fig. 3. Intestinal changes in the activity of cytosolic peptidase (leucine-alanine peptidase) and brush border membrane enzyme (alkaline phosphatase) during the development of sea bass larvae fed adequate diet (unbroken lines) or inadequate diet (broken lines). Data were obtained from ref. 11.

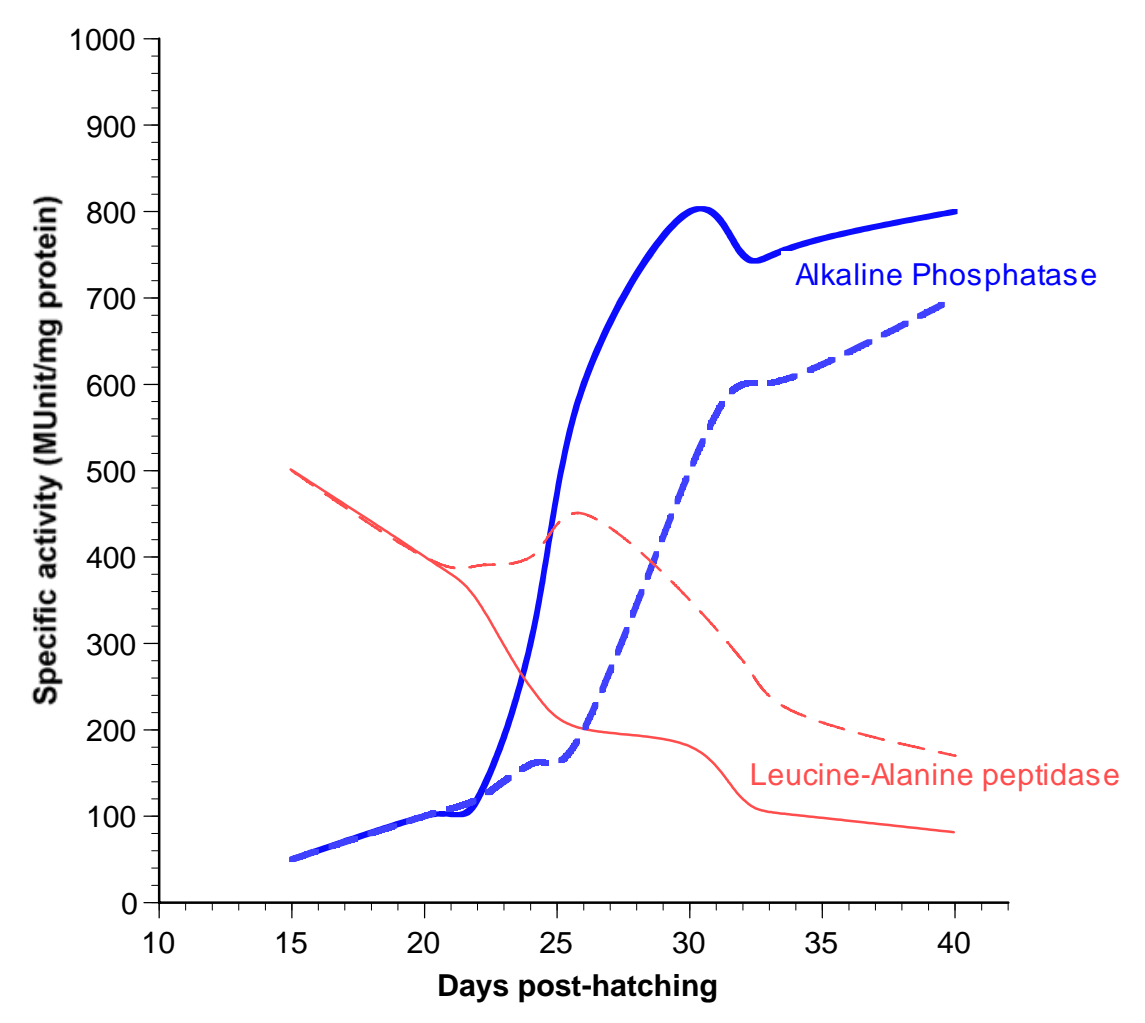




\section{Role of diet on the development of the gastrointestinal tract}

An extensive literature exists on the dietary influence over the regulation of gastrointestinal tract development of the mammals (Henning, 1987). Pancreas and intestine have been mainly studied, and little information exists on stomach, probably because this organ is immature and has a minor part in digestion in developing animals (Henning, 1987). It has been shown that diet plays a secondary role, only determining the maximal or plateau levels of various enzymes in pancreas and intestine, and does not act on the time of their decline or rise that is genetically programmed.

Recent data have revealed that diet globally influences in a similar manner the ontogenic changes in the gastrointestinal tract of fish larvae (Cahu and Zambonino Infante, 1994 and 1995). Nevertheless, these studies have also shown that the maturational process of digestive enzymes can be stopped or delayed when marine fish larvae were fed inadequate diets (Krogdahl and Sundby, 1999). The concept of inadequate diet has been put forward when

marine fish larvae cannot handle formulated diet components due to unique digestive capacities of the larva (Cahu and Zambonino Infante, 1995). This concept also demonstrates the necessity of determining the ability of developing larvae to modulate their digestive enzymes according to the nutrient nature and level in the formulated diet.

\section{III-1. Exocrine pancreas}

As mentioned above, amylase represents a good example for illustrating an ontogenic change in enzyme expression during larvae development. Young larvae exhibited higher amylase activities than older larvae (Péres et al., 1996; Ribeiro et al., 1999b). The decline in amylase specific activity assayed in dissected pancreatic segment in sea bass is coordinated to a decrease in mRNA coding for amylase (Péres et al., 1998); these coordinated processes suggest that the decline in amylase expression is transcriptionally 
regulated during larval development. It has also been shown that the dietary starch content can modulate the decrease in amylase specific activity. This decline was slower in sea bass larvae fed a diet containing $25 \%$ glucides than larvae fed a diet with only $5 \%$ glucides (Fig. 2). Amylase adaptation to the starch level of the diet has been extensively described in mammals (for review see Scheele, 1993) and fish (Kawai and Ikeda, 1973). In the case of sea bass larvae, it can be pointed out that the modulation in amylase activity by dietary starch content is efficient from the day 18 after hatching and would be the result of a posttranscriptional regulation of amylase synthesis (Péres et al., 1998). Red drum larvae also exhibited an efficient modulation of amylase synthesis in response to incorporation of starch in the diet (Buchet et al., 2000).

Nevertheless, it cannot be considered that neither sea bass nor red drum larvae have a predisposition towards utilizing mainly carbohydrates as an energy source during the first 2 weeks post-hatching, since diets containing high glucide levels supported poor growth and survival; moreover, high dietary carbohydrate levels delay the decline of amylase activities (Péres et al., 1996). Amylase expression is then primarily "pre-programmed" and only subtly modified by the diet composition; this is in accordance with the results of studies of the development of pancreatic enzymes in different vertebrate species (Henning et al., 1994; Buddington et al., 1997).

Unlike amylase, the modulation of trypsin by the level of dietary protein content did not occur swiftly in sea bass larvae. Indeed, trypsin activity was directly related to the dietary protein content (from 30\% to 60\% per dry matter) from the 35-day post hatching (Fig. 4), whereas this regulatory process may be not functional in younger larvae (Péres et al., 1996). Variations in trypsin activity have been studied in relation to the level of feed intake in other species (Pedersen et al., 1990), but a clear relationship between trypsin activity and feed intake only occurred after the $5^{\text {th }}$ week of life. Although the mechanisms 
controlling the adaptation of trypsin activity to the amount of dietary protein were not efficient in young larvae, it has been observed that the nature of dietary protein modulated trypsin mRNA transcription and, in some cases, trypsin activity since the $29^{\text {th }}$ day (Péres et al., 1998).

Collectively, these data suggest that different mechanisms control the adaptation of trypsin to the dietary protein amount and to the protein nature in fish larvae. Moreover, these regulatory mechanisms are not turned on at the same time during the maturation of the larvae.

The activity of another protease, chymotrypsin, is also strongly linked to the age in sea bass larvae (Zambonino Infante et al., 1997). Unlike trypsin, chymotrypsin activity is enhanced by diets containing short peptides or protein hydrolysates rather than native proteins (Zambonino Infante et al., 1994).

Fig. 4. Variations in trypsin specific activity in 28-day old and 35-day old sea bass larvae fed different dietary protein levels (from ref. 39).

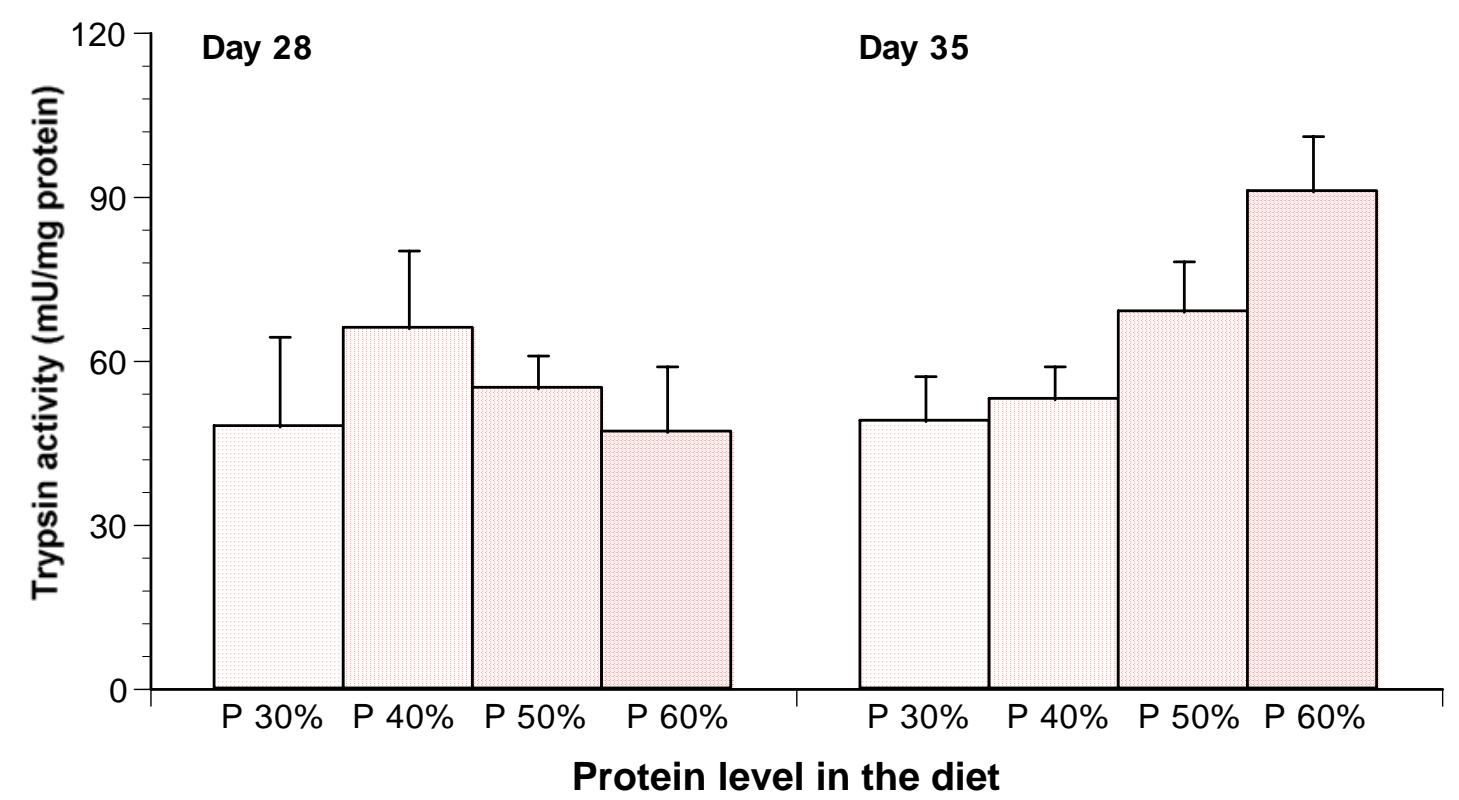


Lipolytic enzymes of pancreas, lipase and phospholipase A2, increase with development of marine fish larvae (Izquierdo et al., 2000), and are stimulated by the increase of their respective substrates, triglycerides and phospholipids in the diet. Such an enzymatic response has been observed in 38-day-old sea bass and 24-day-old red drum larvae (Zambonino Infante and Cahu, 1999; Buchet et al., 2000). Phospholipase A2 activity increases with the level of its corresponding mRNA in sea bass larvae (Zambonino Infante and Cahu, 1999) suggesting a transcriptional regulation of this enzyme. An additional posttranscriptional regulation is also evidenced in sea bass larvae fed diet containing low phospholipid levels. This post-transcriptional regulation is probably mediated by a hormonal mechanism involving cholecystokinin as observed in mammals by Ying et al. (Ying et al., 1993). It can be pointed out that the elevation in activity and mRNA levels of phospholipase A2 reached a plateau in sea bass larvae when diets incorporated more than 4.5\% phospholipids (Fig. 5). A similar plateau is observed for lipase activity in sea bass and red drum larvae respectively fed diets containing $15 \%$ and $12 \%$ triglycerides (Zambonino Infante and Cahu, 1999; Buchet etal., 2000). These plateaus in lipase and phospholipase A2 expression suggest that maximal capacity of lipolytic enzyme synthesis, in developing sea bass and red drum larvae, is reached at $15 \%$ triglycerides and $4.5 \%$ phospholipids in the diet, respectively. 
Fig. 5. Activities and mRNA levels of phospholipase A2 (PLA2) during the development of sea bass larvae fed different dietary phospholipid levels (from ref. 57).

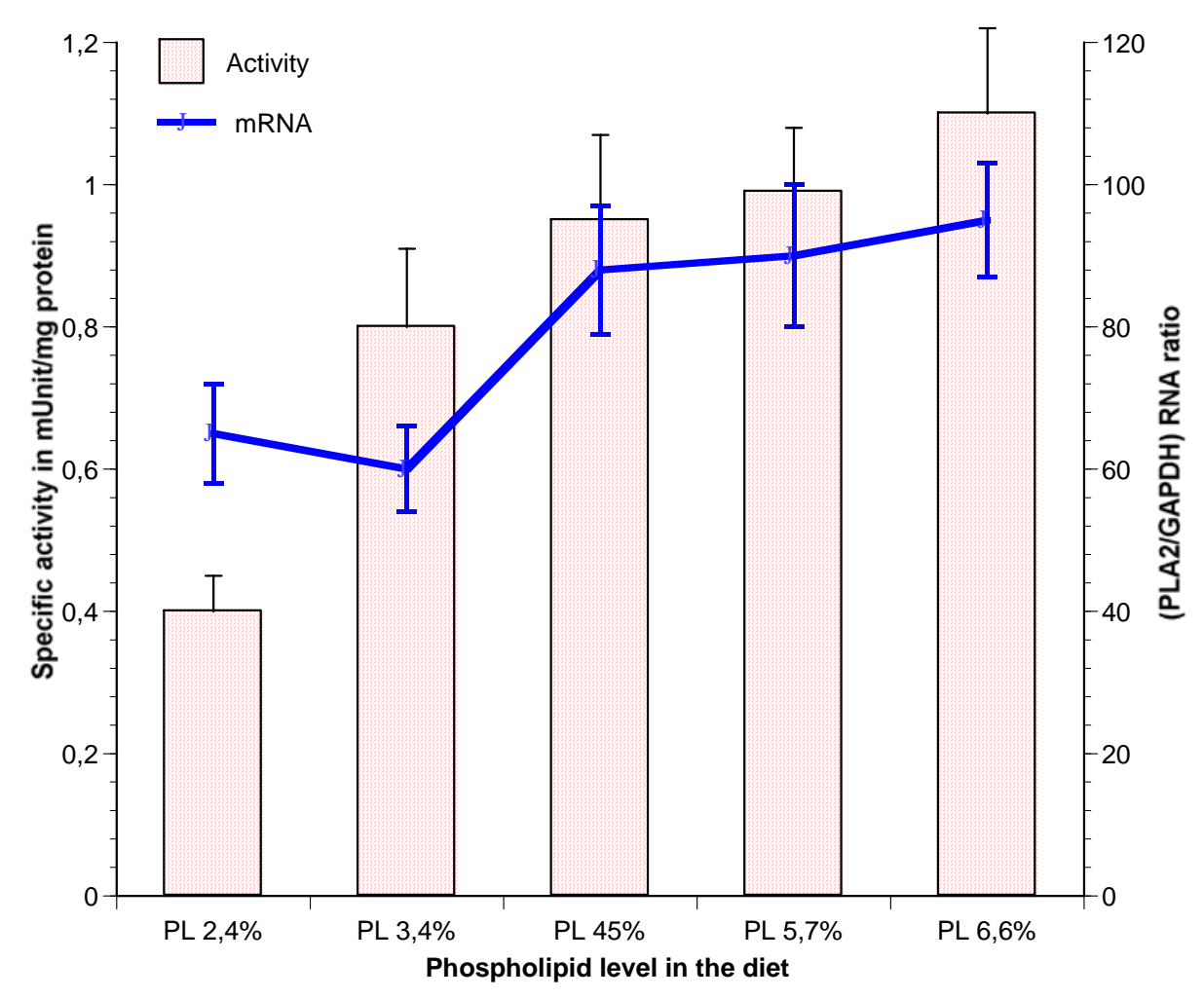

The maturation of the pancreatic secretory process occurs during the first month of life (approximately 600 degree-days) in developing red drum, sea bass and sole larvae, as reported above. It has been observed that feeding sea bass larvae with inadequate diets (diets that does not meet the specific needs of these young larval stages) lead to a disruption of this maturational process (Cahu and Zambonino Infante, 1994): the earlier the feeding with an inadequate diet, the lower the pancreatic secretion level (Fig. 6). Secretion of pancreatic enzymes can be enhanced by the nature of the dietary components (Zambonino Infante and Cahu, 1994) or simply by the size of non-biodegradable particles (Pedersen and Andersen, 1992). The fact that some nutrients and the size of spheres exert a control over pancreatic secretion suggest the coexistence of a chemically and a neural mediated control in marine fish larvae. 
Fig. 6. Level of secretion of amylase and trypsin in the intestinal lumen in sea bass larvae fed an inadequate diet at different developmental times (from ref. 10). Evaluation of secretion is performed on dissected larvae, and expressed as the amount of enzyme in intestinal segment versus the total amount of enzyme in intestinal and pancreatic segment.

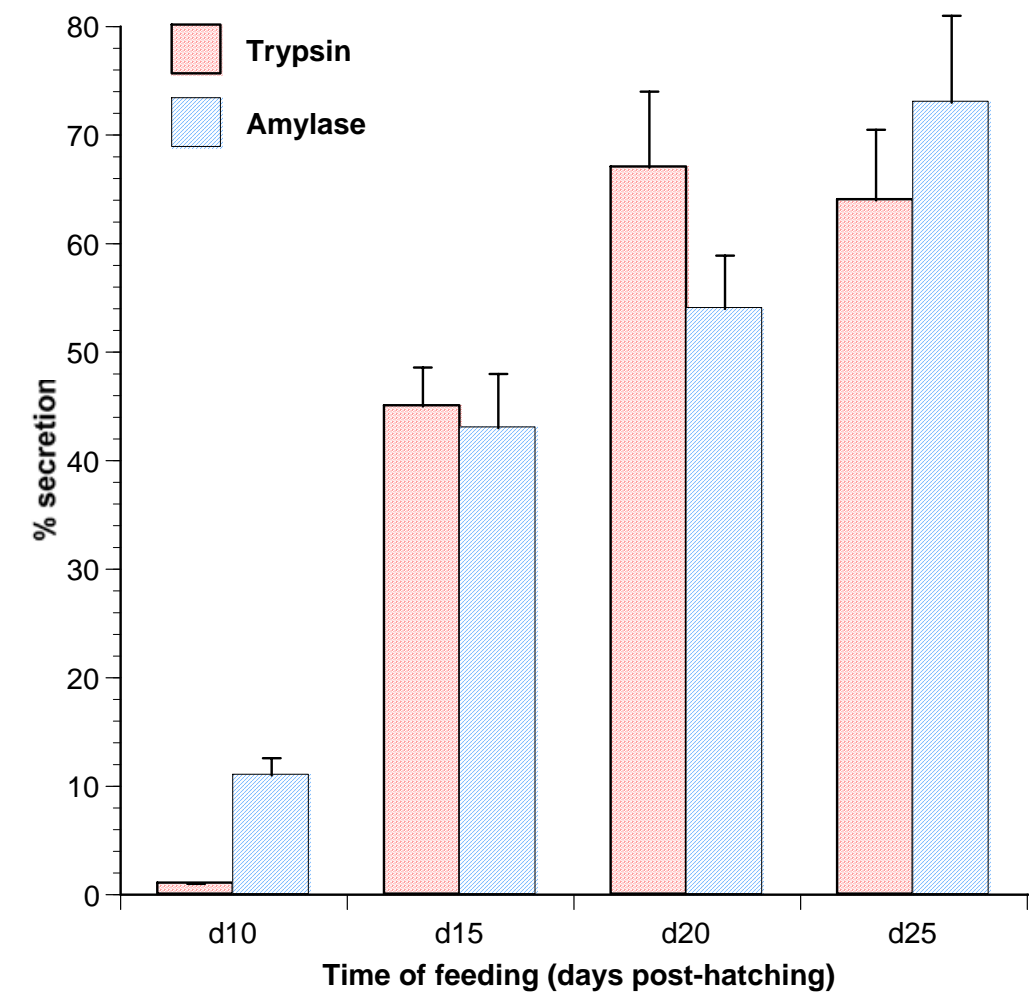

\section{III-2. Intestine}

The enzymatic differentiation of intestinal cells during larvae development leads to a decline in the importance of cytosolic digestion relative to brush-border digestion (Cahu and Zambonino Infante, 1994). With regard to the digestion of dietary proteins, oligopeptides are readily absorbed through the immature brush border membrane of enterocytes, and the final step in protein hydrolysis is carried out by peptides hydrolases located in the cytoplasm. Leucine-alanine peptidase is an enzyme characteristic of the cytosol since the majority of its activity is detected in this subcellular area (Nicholson et al., 1974). As discussed above, leucine-alanine activity is very high during the first 3 weeks of larvae life and progressively decreases with larvae growth (Buchet et al., 1997; Ribeiro et al., 1999b). This decrease is less pronounced in developing larvae fed 
inadequate diets or diets containing high protein hydrolysate levels (Zambonino et al., 1997). It has been shown that the activity of this cytosolic peptidase is much more affected by the age of the larvae than by the protein hydolysate level in the diet; this enzyme provides a good example of an ontogenic change in enzymatic expression at the intestinal level.

A sharp increase (or onset) in brush border membrane enzymes is noted concurrently with the decrease in cytosolic enzymes; this process characterizes the normal maturation of intestine. This maturation process is known to be nutrient-sensitive (Cahu and Zambonino Infante, 1995; Zambonino Infante and Cahu, 1999); an inadequacy between the diet composition and the larvae digestive features may delay or prevent the genetically programmed sequence of intestinal development (Fig. 3). On the other hand, diets containing a moderate amount of protein hydrolysate facilitate this maturational process of the intestine and seem to improve the larvae survival (Cahu and Zambonino Infante, 1995; Zambonino Infante and Cahu, 1999); it has been suggested that diets containing oligopeptides better correspond to the digestive features of fish larvae, allowing a better nutritional status and then an adequate post-natal development. Diets containing more than $20 \%$ lipids (in particular more than $2.7 \%$ eicosapentaenoic and docosahexaenoic acids) also induce an earlier maturation of enterocytes in sea bass (Zambonino Infante and Cahu, 1999) and red drum larvae (Buchet et al., 2000). Other nutrients, like polyamines, also act on enterocyte differentiation; Péres et al. (1998) have shown that sea bass larvae fed a diet containing $0.33 \%$ spermine acquire an enzymatic profile characteristic of mature enterocytes earlier than larvae fed the same diet without spermine.

Other components, like growth enhancing factors, or some micro-organisms (yeast and bacteria) are known to influence intestinal maturation in mammals (Buts et al., 1994; Wong and Wright, 1999), but have been poorly investigated in fish. Nevertheless, it has 
been shown that algal addition (at a level which cannot be considered as a nutritional supply) in sea bass and red drum rearing induces an early maturation of hydrolytic functions of intestinal cell membranes (Lazo et al., 2000).

\section{Conclusion and future directions}

From this review, it must be apparent that the mechanisms controlling the gastrointestinal development at the enzymatic level are very similar between the 3 marine fish species described here. Fish aquaculture of cold water species is getting more and more important, and information on larvae digestive features of these species will be useful for feeding strategies. Nevertheless, generalization to these cold water species like Atlantic halibut, having a long yolk-sac period, is not still possible since little information is available at the moment; the pattern of development appears to be similar ( Kjørsvik and Reiersen, 1992; Gawlicka et al., 2000), but the timeframe is necessarily extended, because of the low temperature optima for rearing and the long period for yolk-sac resorption. The maturational processes described for fish larvae have many things in common with the same processes described for mammals or other vertebrates during the post-natal development. In particular, the chronology of intestinal events for the acquisition of an adult mode of digestion appears highly conserved among species.

Although this review has mainly emphasised enzymatic regulation and changes during post-natal development in marine fish, future investigations in this area should be extended to other aspects, in particular the maturation of transport mechanisms and the role of gastrointestinal hormones during these post-natal changes.

The application of cellular and molecular biology techniques should not be missed. Very few studies (Gjellesvik, 1994; Douglas et al., 1999ab; Zambonino Infante and Cahu, 1999) moved towards these techniques in the area of fish larvae development and nutrition. These 
types of studies are needed for determining whether changes in amount of digestive enzymes reflect control at the level of transcription or translation, and for identifying master genes involved in the regulation of the gut development. New data, essential for a better knowledge of post-natal development in marine fish, will proceed from these studies. 


\section{References}

1. Alliot, E., 1979. Enzymologie digestive. III. Evolution de quelques activités digestives au cours du développement larvaire des téléostéens. In : Fontaine, M. (Ed.), Nutrition des poisons. Actes de Colloques. CNERMA, Paris, pp. 79-87.

2. Alliot, E., Pastoureaud, A., Trellu, J., 1980. Evolution des activités enzymatiques dans le tractus digestif au cours de la vie larvaire de la sole. Variations des protéinogrammes et des zymogrammes. Biochem. Syst. Ecol. 8, 441-445.

3. Beccaria, C., Diaz, J.P., Connes, R., Chatain, B., 1991. Organogenesis of the exocrine pancreas in the sea bass, Dicentrarchus labrax L., reared extensively and intensively. Aquaculture 99, 339-354.

4. Bouhlic, M., Gabaudan, J., 1992. Histological study of the organogenesis of digestive system and swim bladder of the Dover sole, Solea solea (Linnaeus 1758). Aquaculture 102, 373-396.

5. Buddington, R., 1985. Digestive secretions of lake sturgeon, Acipenser fulvencens, during early development. J. Fish Biol. 26, 715-723.

6. Buddington, R., Krogdahl, A., Bakke-Mckellep, A.M., 1997. The intestine of carnivourous fish: structure and functions and the relation with diet. Acta Physiol. Scand. 161, 67-80.

7. Buchet. V., Zambonino Infante, J.L., Cahu, C.L., 1997. Variation in activities of some digestive enzymes during larval development of Sciaenops ocellatus. In: Creswell, L., Harache, Y., (Eds.), Island aquaculture and tropical aquaculture. Communications and abstracts Martinique 97-European Aquaculture Society International Conference, Les Trois Ilets, Martinique, 4-9 may 1997. European Aquaculture Society, Oostende, pp. $55-56$. 
8. Buchet, V., Zambonino Infante, J.L., Cahu, C.L., 2000. Effect of lipid level in a compound diet on the development of red drum (Sciaenops ocellatus) larvae. Aquaculture 184, 339-347.

9. Buts, J.P., De Keiser, De Raedemaeker, L., 1994. Saccharomyces boulardii enhances rat intestinal expression by endoluminal release of polyamines. Pediatr. Res. 36, 522527.

10. Cahu, C., Zambonino Infante, J.L., 1994. Early weaning of sea bass (Dicentrarchus labrax) larvae with a compound diet: effect on digestive enzymes. Comp. Biochem. Physiol. 109A, 213-222.

11. Cahu, C., Zambonino Infante, J.L., 1995. Effect of the molecular form of dietary nitrogen supply in sea bass larvae : response of pancreatic enzymes and intestinal peptidases. Fish Biochem. Physiol. 14, 209-214.

12. Clark, J., Murray, K.R., Starck, J.R., 1986. Protease development in Dover sole (Solea solea L.). Aquaculture 53, 253-262.

13. Douglas, S.E., Gallant, J.W., Bullerwell, C.E., 1999a. Molecular investigation of aminopeptidase $\mathrm{N}$ expression in the winter flounder, Pleuronectes americanus. J. Appl. Ichthyol. 15, 80-86.

14. Douglas, S.E., Gawlicka, A., Mandla, S., Gallant, J.W., 1999b. Ontogeny of the stomach in winter flounder: characterization and expression of the pepsinogen and proton pump genes and determination of pepsin activity. J. Fish Biol. 55, 897-915.

15. Douglas, S.E., Mandla, S., Gallant, J.W., 2000. Molecular analysis of the amylase gene and its expression during the development in the winter flounder, Pleuronectes americanus. Aquaculture 190, 247-260. 
16. Gawlicka, A., Parent, B., Horn, M.H., Ross, N., Opstad, I., Torrissen, O.J., 2000. Activity of digestive enzymes in yolk-sac larvae of Atlantic halibut (Hippoglossus hippoglossus): indication of readiness for first feeding. Aquaculture 184, 303-314.

17. Gjellesvik, D.R., Lorens, J.B., Male, R., 1994. Pancreatic carboxylester lipase from atlantic salmon (Salmo salar) cDNA sequence and computer-assisted modelling of tertiary structure. Eur. J. Biochem. 226, 603-612.

18. Henning, S.J., 1987. Functional development of the gastrointestinal tract. In : Johnson, L.R. (Ed.), Physiology of the gastrointestinal tract. $2^{\text {nd }}$ edition. Raven Press, New York, pp. 285-300.

19. Henning, S.J., Rubin, D.C., Shulman, R.J., 1994. Ontogeny of the intestinal mucosa. In: Johnson, L.R. (Ed.), Physiology of the gastrointestinal tract. $3^{\text {rd }}$ edition. Raven Press, New York, pp. 571-610.

20. Himukai, M., Kono, T., Hoshi, T., 1980. Age-dependent change in intestinal absorption of dipeptides and their constituent amino acids in the guinea pig. Pediatr. Res. 14, 1272-1275.

21. Holt, J.G., Johnson, A.G., Arnold, C.R., Fable, W.A., Williams, T.D., 1981. Description of eggs and larvae of laboratory reared red drum Sciaenops ocellata. Copeia 4, 751-756.

22. Holt, J.G., Sun, F., 1991. Lipase activity and total lipid content during early development of red drum Sciaenops ocellatus. In: Lavens, P., Sorgeloos, P., Jaspers, E., Ollevier, F., (Eds.), Larvi’91- Fish \& Crustacean larviculture symposium. Special publication 15. European Aquaculture Society, Gent,:30-33.

23. Izquierdo, M.S., Socorro, J., Arantzamendi, L., Hernandez-Cruz, C.M., 2000. Recent advances in lipid nutrition in fish larvae. Fish Biochem. Physiol. 22, 97-107. 
24. Kawai, S., Ikeda, S., 1973. Studies on digestive enzymes of fishes. III. Development of the digestive enzymes of the rainbow trout after hatching and the effect of dietary change on the activities of digestive enzymes in the juvenile stage. Bull. Jap. Soc. Sci. Fish. 39, 819-823.

25. Kjørsvik, E., Reiersen, A.L., 1992. Histomorphology of the early-sac larvae of the Atlantic halibut (Hippoglossus hippoglossus L.)- an indication of the timing of functionality. J. Fish Biol. 41, 1-19.

26. Kolkovski, S., 2001. Digestive enzymes in larvae and juvenile-implications and application to formulated diets. Aquaculture in press.

27. Kolkovski, S., Tandler, A., Kissil, G.W., Gertler, A., 1993. The effect of dietary exogenous digestive enzymes on ingestion, assimilation, growth and survival of gilthead seabream larvae. Fish Physiol. Biochem. 12, 203-209.

28. Kolkovski, S., Tandler, A., Izquierdo, M.S., 1997. Effects of live food and dietary digestive enzymes on the efficiency of microdiets for seabass (Dicentrarchus labrax) larvae. Aquaculture 148, 313-322.

29. Koven, W., Kolkovski, S., Hadas, E., Gamsiz, K., Tandler, A., 2001. Advances in the development of microdiets for gilthead seabream, Sparus aurata: a review. Aquaculture 194, 107-121.

30. Krogdahl, A., Sundby, A., 1999. Characteristics of pancreatic function in fish. In: Pierzynowski, S.G., Zabielski, R. (Eds.), Biology of the pancreas in growing animals. Elsevier Science, Amsterdam, pp. 437-458.

31. Lazo, J.P., Holt, G.J., Arnold, C.R., 2000. Ontogeny of pancreatic enzymes in larval red drum Sciaenops ocellatus. Aquaculture Nutr. 6, 183-192. 
32. Lazo, J.P., Dinis, M.T., Holt, G.J., Faulk, C., Arnold, C.R., 2000. Co-feeding microparticulate diets with algae: toward eliminating the need of zooplankton at first feeding in larval red drum (Sciaenops ocellatus). Aquaculture 188, 339-351.

33. Lowe, M.E., 1994. The structure and function of pancreatic enzymes. In: Physiology of the gastrointesnal tract. In: Johnson, L.R. (Ed.), Physiology of the gastrointestinal tract. $3^{\text {rd }}$ edition. Raven Press, New York, pp. 1531-1542.

34. Martinez, I., Moyano, F.J., Fernandez-Diaz, C., Yufera, M., 1999. Digestive enzyme activity during larval development of the Senegal sole (Solea senegalensis). Fish Physiol. Biochem. 21, 317-323.

35. Nicholson, J.A., McCarthy, D.M., Kim, Y.S., 1974. The responses of rat intestinal brush border and cytosol peptide hydrolase activities to variation in dietary protein content. J. Clin. Invest. 54, 890-898.

36. Ozkizilcik, S., Chu, F.L., Place, A.R., 1996. Ontogenetic changes of lipolytic enzymes in striped bass (Morone saxatilis). Comp. Biochem. Physiol. 113B, 631-637.

37. Pedersen, B.H., Andersen, K.P., 1992. Induction of trypsinogen secretion in herring larvae (Clupea harengus). Mar. Biol. 112, 559-565.

38. Pedersen, B.H., Ugelstad, I., Hjelmeland, K., 1990. Effects of a transitory, low food supply in the early life of larval herring (Clupea harengus) on mortality, growth and digestive capacity. Mar. Biol. 107, 61-66.

39. Péres, A., Cahu, C.L., Zambonino Infante, J.L., Legall, M.M., Quazuguel, P., 1996. Amylase and trypsin responses to intake of dietary carbohydrate and protein depend on the developmental stage in sea bass (Dicentrarchus labrax) larvae. Fish Physiol. Biochem. 15, 237-242. 
40. Péres, A., Cahu, C.L., Zambonino Infante, J.L., 1997. Dietary spermine supplementation induces intestinal maturation in sea bass (Dicentrarchus labrax) larvae. Fish Physiol. Biochem. 16, 479-485.

41. Péres, A., Zambonino Infante, J.L., Cahu, C.L., 1998. Dietary regulation of activities and mRNA levels of trypsin and amylase in sea bass (Dicentrarchus labrax) larvae. Fish Physiol. Biochem. 19:145-152.

42. Ribeiro, L., Sarasquete, C., Dinis, M.T., 1999a. Histological and histochemical development of the digestive system of Solea senegalensis (Kaup 1858) larvae. Aquaculture 171, 293-308.

43. Ribeiro, L., Zambonino Infante, J.L., Cahu, C., Dinis, M.T., 1999b. Development of digestive enzymes in larvae of Solea senegalensis, Kaup 1858. Aquaculture 179, 465473.

44. Rønnestad, I., Thorsen, A., Finn, R., 1999. Fish larval nutrition: a review of recent advances in the role of amino acids. Aquaculture 177, 201-216.

45. Sarasquete, C., Gonzales de Canales, M.L., Arellano, J.M., Muñoz-Cueto, J.A., Ribeiro, L., Dinis, M.T., 1996. Histochemical aspects of the yolk-sac and digestive tract of larvae of the Senegal sole, Solea senegalensis (Kaup, 1858). Histol. Histopathol. 11, 881-888.

46. Sheele, G.A., 1993. Regulation of pancreatic gene expression in response to hormones and nutritional substrates. In: GO, V.L., Gardner, J.D., Brooks, F.P., Lebenthal, E. (Eds.), The pancreas: biology, pathobiology, and disease. $2^{\text {nd }}$ edition. Raven Press, New York, pp. 103-120.

47. Scheele, G.A., Kern,, H.F., 1993. Cellular compartmentation, protein processing, and secretion in the exocrine pancreas. In: GO, V.L., Gardner, J.D., Brooks, F.P., 
Lebenthal, E. (Eds.), The pancreas: biology, pathobiology, and disease. $2^{\text {nd }}$ edition. Raven Press, New York, pp. 121-150.

48. Vu, T.T., 1976. Etude du développement du tube digestif des larves de bar Dicentrarchus labrax (L.). Arch. Zool. exp. gen. 117, 493-509.

49. Walford, J., Lam, T.J., 1993. Development of the digestive tract and proteolytic enzyme activity in seabass (Lates calcarifer) larvae and juveniles. Aquaculture 109, 187-205.

50. Watanabe, T., Kiron, V., 1994. Prospects in larval fish dietetics. Aquaculture 124, 223-251.

51. Wong, W.M., Wright, N.A., 1999. Epidermal growth factor, epidermal growth factors receptors, intestinal growth, and adaptation. JPEN (J. Parent. Enter. Nutr.) 23, S83S88.

52. Ying, Z., Tojo, H., Nonaka, Y., Okamoto, M., 1993. Cloning and expression of phospholipase A2 from guinea pig gastric mucosa: its induction by carbachol and secretion in vivo. Eur. J. Biochem.; 215:91-97.

53. Yufera, M., Pascual, E., Fernandez-Diaz, C., 1999. A highly efficient microencapsulated food for rearing early larvae of marine fish. Aquaculture 177, 249256.

54. Zambonino Infante, J.L., Cahu, C.L., 1994. Influence of diet on pepsin and some pancreatic enzymes in sea bass (Dicentrarchus labrax) larvae. Comp. Biochem. Physiol. 109A, 209-212.

55. Zambonino Infante, J.L., Cahu, C.L., 1994. Development and response to a diet change of some digestive enzymes in sea bass (Dicentrarchus labrax) larvae. Fish Physiol. Biochem. 12, 399-408. 
56. Zambonino Infante, J.L., Cahu, C.L., Peres, A., 1997. Partial substitution of di- and tripeptides for native proteins in sea bass diet improves Dicentrarchus labrax development. J. Nutr. 127, 608-614.

57. Zambonino Infante, J.L., Cahu, C.L., 1999. High dietary lipid levels enhance digestive tract maturation and improve Dicentrarchus labrax larval development. J. Nutr. 129, 1195-1200. 